\title{
Who Cares If Rhetoricians Landed on the Moon? Or, a Plea for Reviving the Politics of \\ Historiography
}

\author{
Ryan Skinnell
}

$[\mathrm{H}]$ istories of our tradition are rhetorical acts, the products of the historian's own cultural milieu. Narratives . . . of our tradition are governed by the historian's commitment to a system of beliefs nourished in the present. However "faithful" it may presume to be to historical events, an account of the past inevitably endorses a specific set of valuations, defends a particular set of social, political and economic relations, and advocates a specific direction for contemporary society (175). Takis Poulakos, "Historiographies of the Tradition of Rhetoric: A Brief History of Classical Funeral Orations"

A critique is not a matter of saying that things are not right as they are. It is a matter of pointing out on what kinds of assumptions, what kinds of familiar, unchallenged, unconsidered modes of thought the practices that we accept rest. . . Practicing criticism is a matter of making facile gestures difficult. (154-155). Michel Foucault, "Practicing Criticism"

No one, to my knowledge, has claimed that rhetoricians landed on the moon. ${ }^{1}$ As far as I know, only twelve astronauts did, Neil Armstrong and Edwin "Buzz" Aldrin being the most celebrated. ${ }^{2}$ Given recent reductions in NASA's budget, chances to place a rhetorician in orbit are effectively on hold. Still, I imagine rhetoricians would be pleased if one of their number landed on the moon. The notion of an astral rhetorician or a rhetorical astronaut is rich because it evokes boundless horizons and incorporates the belief that occupying new horizons can reorient 
our sense of what it means to inhabit old scenes and perhaps even reorient the old scenes themselves. This promise of critical perspective corresponds to a promise in contemporary histories of rhetoric - that seeking new (rhetorical) horizons can induce healthy contemplation about what it means to study, teach, and write history, and can thereby transform the conditions in which these actions take place. At the outset, then, I offer the cosmological image of "rhetoricians on the moon" to frame my preliminary claim that much current historical research in rhetorical studies is underwritten by an imperative to "broaden" the field's horizons in order to develop new perspective(s) on and for the field.

This tropological "broadening imperative" is closely linked to historiographical theories of "revisionary history," which James Berlin, an early proponent, defined as "the search for the excluded other...exploring the margins, examining the supplement - the excluded and silenced-and giving it voice" ("Octalog” 35). If history is conventionally written by victors, Berlin entreats historians to attend to the vanquished ("History" 146). Revisionary history cuts across disciplines and incorporates complex, and sometimes competing, goals. But at its core, revisionary history focuses on broadening the field's vision by searching for people, movements, or methods excluded from canonical histories. By broadening the field's vision of what can be considered "rhetorical," revisionary historians have made significant interventions in the history of rhetoric. They have participated in, and often spearheaded, the re(dis)covery of non-male, non-white, non-Western, non-normative, non-privileged, and more recently, non-human, historical actors. ${ }^{3}$ Small historical steps and giant disciplinary leaps notwithstanding, however, this essay is not a catalogue of revisionary successes. In fact, "rhetoricians on the moon" is a generative symbol because it comprises conflicting notions of (space) exploration. On one hand, the inexhaustible supply of research subjects suggested by unreachable horizons is exciting; on 
the other hand, "broadening" threatens to become the grounds on which revisionary historiography exists rather than a tropological appeal for developing perspective(s).

The latter is the argument I intend to make — as a result of rhetorical studies' changing political and intellectual conditions over the past three decades, "broadening" is no longer necessarily connected to the search for critical perspectives around which it developed. Byron Hawk makes a similar point when he claims that, "revisionary history has given way to bureaucratic mandate (retrieve the excluded)" (110). Apropos Hawk, I contend that the majority of contemporary revisionary histories are not "revisionary" in Berlin's critical sense of the term because historians connect the broadening imperative to the disciplinary project of developing a more "complete" historical picture. Consequently, contemporary revisionary histories are often pitched toward reinforcing the field's beliefs instead of critically examining them. Revisionary historiography has therefore come to serve preservative, regulatory functions, which are at odds with revisionaries' declared critical, progressive aims. ${ }^{4}$ In addition to its inspirational evocations, then, "rhetoricians on the moon" offers a productive metaphor for considering tensions that threaten to undermine the critical project of revisionary historiography.

To make this case, my argument consists in three parts: first, I survey recent histories to situate the contemporary "broadening imperative" relative to the context in which it developedthe canon wars of the 1980s and 1990s. Second, I argue that shifts in the field's political and intellectual conditions over the past three decades have caused a concomitant, if largely unremarked, shift in exigencies for historical work. As a result, an important shift has also occurred in revisionary histories' disciplinary purposes_-from iconoclasm to preservation. Third, I contend that historians need to revive the critical practice entailed in the politics of historiography_-discussions in the 1980s and 1990s that foregrounded critique (e.g., 
Who Cares if Rhetoricians Landed on the Moon? 4

“Octalog”). ${ }^{5}$ I define critique narrowly, following Michel Foucault and Judith Butler, as the practice of "pos[ing] the question of the limits of our most sure ways of knowing" (Butler 215; Foucault "Practicing" and "What"). For rhetoric and composition historians, the form of critique I am proposing necessitates actively challenging and openly discussing the stakes of historical work. In other words, critique is not a rejection of historical research, nor a rejection of methodological assumptions - it is rigorous examination of the values historians advance, knowingly or not. Such examination entails the productive distance implicit in travelling to the moon to analyze the Earth. Ultimately, if revisionary historians value the radical perspective implied in the act of "revisioning," it is necessary to reinvest in the kinds of critical interrogation that characterized first-generation historians three decades ago.

\section{Defining Revisionary History/ies}

Most contemporary histories of rhetoric are revisionary. This is not a particularly controversial claim, so an extensive catalogue of examples is unnecessary. Still it is worth detailing some evidence. The September 2012 issue of College Composition and Communication, which focused on the field's research methods and methodologies, offers a representative example. Out of nine full-length essays in the volume, four discuss histories in more or less direct ways - a strong indicator of historical work's importance to the field. Each of the four assumes a revisionary lens, which is to say they all advocate or assume the broadening work characteristic of revisionary historiography. Lynée Lewis Gaillet asserts that one goal of twenty-first century archival research is "complicating existing narratives" (35); in discussing archival research ethics, Heidi McKee and James Porter write, "Within rhetoric and composition studies, the actual 'what' of an archive is likewise expansive and ever-expanding, in part because scholars have challenged researchers to look beyond canonized public figures to include the 
public and private writings of women and people of color and, by extension, the rhetoric of any and all persons who may be overlooked" (61); and Shannon Carter and James H. Conrad expressly advocate recovering underrepresented voices through collecting and digitizing oral histories in local communities (81-82). In his lead article, "Remapping Revisionist Historiography," David Gold makes the most explicit case for revisionary historiography's centrality in the field. Gold maintains that revisionary historiography has become "the norm," (29) and historians can assume "a complex, multivocal past as our starting point" (17).

Each historically-minded essay in the issue makes plain that revisionary historiography is the default historiographical framework in rhetoric and composition, and the same is true in rhetorical studies at large. And if revisionary historiography is the default framework, the broadening imperative remains at the heart of it. The necessary caveat is that not all contemporary histories are revisionary. ${ }^{6}$ Nevertheless, revisionary historiography's predominance is powerfully reinforced when one surveys recent work in the field. ${ }^{7}$

In pointing out the prevalence of revisionary historiography, my goal is not to question the quality of historical research, but to raise concerns about implicit methodological assumptions in the revisionary framework. On their own terms, many revisionary histories are excellent examples of historical research. However, I maintain that contemporary revisionary histories are generally not "revisionary," at least in the critical sense delineated by Berlin and others. That is, the historiographical position I describe as the field's default framework is "revisionary" in the sense that it extends the disciplinary project of first-generation revisionaries (e.g., Berlin, Susan Jarratt, and John Schilb); and certainly historians that practice contemporary versions of "revisionary" historiography borrow methodological assumptions from previous versions of revisionary historiography, the two most notable being: (1) challenging and 
Who Cares if Rhetoricians Landed on the Moon? 6

complicating traditional histories, and (2) investigating marginalized subjects to advance this revisioning. But despite the outward appearance of revisionary appeals, by and large, contemporary histories do not meet the critical goals that characterized earlier revisionary histories. $^{8}$

To demonstrate how contemporary revisionary histories differ from previous ones, I need to outline some of the key aims of revisionary historiography in the work of first-generation revisionaries. There are, of course, important distinctions among these historians that I ignore by grouping them together, but in many ways their historiographical project was consistent even if their arguments for carrying it out diverged (see Graff and Leff 22). ${ }^{9}$ A primary goal of firstgeneration revisionaries, again according to Berlin, was to call into question the ideological conditions that constituted the present moment. Berlin asserts, "The past cannot be regarded as existing simply to produce the present or as a prefiguration of it" ("History" 145). For Berlin, seeking out "the vanquished" helped historians recognize competing voices in past historical periods, which consequently helped historians interrogate ideological investments that are naturalized in the present.

Reflecting critically on the present moment was an explicit function of revisionary histories in the 1980s and 1990s. Revisionary history gained purchase in the academy during the culture wars of the $80 \mathrm{~s}$ and $90 \mathrm{~s}$, concurrent with academic interests in theories of gender, race, sexuality, and class. This was not incidental. Revisionaries were openly subversive in the face of the oppressive logics of the traditional canon. ${ }^{10}$ Susan Jarratt argued in 1987 that revisionary histories constituted radical, political action, writing, "The movement from a disciplinary 'history of rhetoric' to a post-disciplinary rhetorical historiography demands an expansion of the field of study. ... In terms of physical evidence and pedagogical practice, the point is most 
radically to reconsider the notion of a canon" ("Toward" 13 ; see also Rereading 14). Revisionary history was fundamentally iconoclastic and targeted the prevailing wisdom that canons represented the sum total of what students "needed to know." Revisionary historians believed to the contrary that canonical histories ignored the meaningful contributions of women, people of color, gays and lesbians, non-Western rhetors, and members of the working classes.

Revisionaries therefore advocated "broader" histories to alter the intellectual and material conditions in which they worked.

Although broadening was an important tool for first-generation historians, the ultimate goal was not recovering and reconstituting overlooked subjects, per se. The broadening imperative was a means to effect political change within rhetoric and composition-whether by challenging capitalist hegemony in university writing instruction (Berlin); challenging men's "natural" rhetorical superiority (Jarratt); or challenging the dominance of literary studies (Crowley). As one example, feminist historian Cheryl Glenn argued in Rhetoric Retold that there was much to learn from studying women's contributions to the history of rhetoric, but doing so required confronting a canon that reserved intellectual significance for men. Glenn writes, “"The History of Rhetoric' is quickly displaced by questions. Whose history? Whose rhetoric? Which rhetoric? All necessary challenges to a canon that continues to be so unrelentingly elite and male" (5). For Glenn, the stakes were high because of histories' influences on contemporary political, ideological, and pedagogical conditions. She writes: "[T]he project of regendering rhetorical history is a feminist performative act, a commitment to the future of women, a promise that rhetorical histories and theories will eventually (and naturally) include women." She asserts, moreover, that regendering "unsettles stable gender categories and enacts a promise that 
rhetorical history will be a continuous process of investigating the works of women and men rather than a final product that can be finally or universally represented" (174).

In Glenn's work, broadening the history of rhetoric to include female rhetors challenged the prevailing belief that men were "natural" orators and women were naturally not. Moreover, broadening induced a fundamentally changed future and "enacted a promise" of gender inclusivity. Whether or not Glenn's promise has been fully enacted, first-generation revisionary historians' political project of unsettling the canon shaped the discipline in subsequent years in very real ways by affecting what teachers can teach, what students can learn, and what scholars can study. The field broadly reflects the inclusion of non-traditional subjects, including women, that revisionaries began agitating for three decades ago. ${ }^{11}$

\section{Revisioning Revisionary Histories}

Revisionary histories were, at one time, subversive, iconoclastic, canon-busters. But times have changed, at least where the canon is concerned. What was the "traditional" canon is not gone, but it has been challenged, complicated, and broadened. We might say that it has been effectively busted and to good effect. As a consequence, however, the exigencies of revisionary historiography have shifted, and the political goals that were once associated with revisionary histories in the academy are now somewhat passé. I use the modifier "somewhat" advisedly because, while I am not under the naïve impression that "non-traditional" rhetoricians such as Aspasia are as highly valued as Cicero and Aristotle, neither do I think non-canonical figures are excluded from research programs and rhetoric classes as a matter of policy. To be clear, I realize histories of rhetoric are still exclusionary in many ways. Charles E. Morris III and K.J. Rawson make this point persuasively in "Queer Archives/Archival Queers"; and Malea Powell likewise makes a powerful, if (in her words) "imprecise" claim about the exclusionary practices of the 
discipline (“Octalog II” 121). I do not dispute these, and similar, arguments. Nevertheless, the politics that provoked canon-busting in the 1980s and 1990s are significantly different following revisionary historians' successes.

As the political landscape has changed, so too have the purposes of revisionary histories. The central revisionary methods — searching for excluded others, exploring the margins, and giving voice to the silenced-have remained, but divorced from the specific exigency of canonbusting, the methods have largely become ends unto themselves (i.e., Hawk's "bureaucratic mandate"). As I argued above, revisionary historiography is now the dominant theoretical frame for histories of rhetoric, which means it is normative, and therefore significantly less critical of the discipline. In place of critical canon-busting, broadening has become a project of accretion: adding nuance to develop a more "complete" history of the field—what Wendy Hesford has identified as "a recovery-and-recognition enterprise" (793). The revisionary project has been redefined such that historians now regularly justify their work on the grounds that broadened histories result in "better," "fuller," "truer," "more nuanced," "more transparent," even "more objective" histories.

The alignment of revisionary methods with the many forms of objectivity is striking given many first-generation revisionaries' explicit rejection of objectivity (Berlin, "Histories"; Blair and Kahl; Jarratt, Rereading; Poulakos; Schilb, "Future" and "History"; Vitanza, "Critical" and $\underline{\text { Negation}}$. This rejection was intimately linked to revisionaries' adoption of post-structural and/or postmodern views of history and language, which were antithetical to claims of objectivity. There is not room here to give this shift as much attention as it deserves, but firstgeneration revisionaries' rejection of objectivity was no small matter. More to my point, the search for more "complete" and "objective" historical knowledge reflects an appeal to 
"broadening" that is not in the service of critically revisioning — or even questioning — the field's contemporary beliefs. It is instead a way to locate histories that strengthen the field's central ideologies. It is a project of expansion and preservation rather than iconoclasm and perspectivalism.

To clarify, I am not claiming historians have abandoned their political engagements. I am not making that case because it is demonstrably not true. At the Conference on College Composition and Communication in 2011, for instance, eight prominent rhetoric and composition scholars participated in "Octalog III," the third in a series of panels dedicated to considering the politics of historiography (see, "Octalog"; “Octalog II"). Each member of "Octalog III" offered critiques of the field that bear serious attention, and most advocated forms of revisionary research to address the issues. Nonetheless, I feel justified in claiming that most contemporary revisionary histories are not revisionary in the first-generation sense because of the ways they connect the broadening imperative to an investment in a more "full" and "complete" picture of the field's history. Put differently, the political critiques advanced in "Octalog III" described ways to achieve the field's goals better rather than raising critical questions about the advisability of those goals. It is not that contemporary revisionary histories do not offer us new ways of seeing the world. Oftentimes they do. But, by and large, they do not invite the kinds of critical interrogation of the present that Berlin, et al. once advocated.

The one Octalogonal exception was Ronald Jackson, who offered a pointed critique of the ongoing practice of teaching the history of rhetoric as a predominantly White tradition (“Octalog III," 117-118). Although specifically concerned with pedagogy, and not necessarily with historical research, Jackson offers a good example of the kind of critique I am calling for in that he interrogates the unspoken assumptions entailed in teaching histories of rhetoric. Jackson's 
example notwithstanding, and despite the now-conventional assertion by revisionary historians that they are "challenging master narratives," which invokes the old iconoclasm, practitioners of revisionary historiography tend to promote histories that strengthen and naturalize the field's ideological investments and thereby deflect serious critique of the field's central assumptions. Obviously this is a provocative claim, so it is worth offering examples.

I take David Gold's book, Rhetoric at the Margins: Revising the History of Writing Instruction in American Colleges as my first example. As should be clear from the title, Gold's book is a revisionary history par excellence-it seeks rhetoric at the margins to revise the history of writing instruction. In his study, Gold examines rhetorical education at three non-traditional colleges around the turn of the twentieth century. In particular, he investigates pedagogical practices that rhetoric and composition specialists think of as objectionable - prescriptive language instruction, for example — and argues that such practices served liberatory ends within particular historical circumstances. In framing his claims, Gold relies on a central justification of revisionary historiography — that investigating underexplored/underrepresented subjects can productively challenge the traditional history of rhetoric. He contends that the experiences of students and teachers at non-elite institutions can "complicate and confound received historical narratives," and his case studies therefore "offer a more nuanced and representative picture of the past" that calls into question established beliefs about pedagogy's connections to political ideology (ix).

It is not my intention to contradict Gold's general conclusions or dispute the quality of his historical work. In fact I chose his book because it is exemplary, having been well received and widely cited in the field. It was understandably awarded the 2010 Conference on College

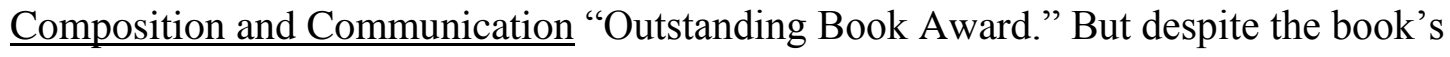


excellence, or maybe because of it, my attention has been repeatedly drawn to a minor claim that Gold makes in his conclusion, "History Matters." Gold argues that the kind of revisionary historiography represented by his book is important because it enables political action. He writes, "Such histories matter and not merely to historians but to teachers, administrators, policymakers, and the public.... If we, as instructors and scholars of rhetoric and writing, are to have a say in that future, we must be able to articulate a nuanced interpretation of our past" (152-153). It is an ambitious and unequivocal assertion of the stakes of his historical work.

Gold's claim that nuanced histories enable political efficaciousness is also dubious. Nevertheless, it sheds some light on the underlying tensions between first-generation iconoclasm and contemporary preservationism. In establishing his frame, Gold evokes first-generation iconoclasm by gesturing to multivocality, diversity, and complexity in the field's histories. He is undeniably invested in "recover[ing] important histories that would otherwise be lost and giv[ing] voice to the experiences of students and educators of a diverse past" and "complicat[ing] and challeng[ing] the master narratives of rhetoric and composition and the ideological assumptions that underlie them" (x). These are two chief goals of revisionary histories as firstgeneration historians defined them. However, the implications of Gold's argument as he enumerates them are predominantly preservative. He concludes that rhetoricians' access to cultural power in the present and future is predicated on historians' ability to establish a unified, if polysemous, tradition of existence. Put differently, his concluding appeal is not for critiquing the status quo and questioning its limitations, but for reinforcing the status quo to enable political action.

Gold's call for nuance might, in fact, be read as a suggestion for historians to correct and strengthen the master narrative instead of radically rethinking it. In claiming that nuanced 
histories enable specialists' participation in political discussions, for instance, Gold reasserts some of the field's most enduring ideological investments: (1) empowering students, (2) linking rhetorical instruction to democratic action, (3) developing locally responsive pedagogies. He gestures to a fourth: strengthening rhetoricians' disciplinary/political influence. These ideological investments are not necessarily bad, of course, but neither are they critically revisionary.

To the contrary, these ideological commitments are central to rhetorical studies-a conclusion that is not hard to demonstrate and is perhaps not even controversial. The progression of these goals from the field's periphery to its center can be inferred from Sharon Crowley's "Afterword" in the recent collection, Theorizing Histories of Rhetoric. "As I recall," Crowley writes, “Jim [Berlin]'s work shook up some folks because he actually took first-year composition seriously enough to attempt writing its history. But it was his historiographical approach — social, located, time-bound, and most of all, political — that was little short of revolutionary" (192). Crowley's recollection is accompanied by her sense that "the old fervor" of historiographical squabbles in the 1980s and 1990s is now missing because resistance to Berlin's "revolutionary" historiographical approach is now gone (190).

As I read Crowley, the ideologies that were radical in Berlin's work have become axiomatic - they are no longer divisive. In effect, the ideological commitments in Gold's book are now so commonplace that they "need not be defended with passion" (195). "Revisionary" appeals to these ideological investments hearken to a past political project as if it were still radical, but it is not. I hesitate to call contemporary revisionary historiography "conservative," given the specific connotations "conservatism" carries in American politics; but it is conservative 
(small "c") inasmuch as it represents an attempt to strengthen and naturalize the field's core values rather than critically revisioning them. ${ }^{12}$

The broadening imperative's connection to efforts at consolidating the field's political influence indicates that, as a historiographical trope, "broadening" is not inseparable from the critical goals of first-generation revisionaries_- "broadening" can serve preservative/conservative functions. Absent a canon in need of "revision," therefore, revisionary historians face a considerable challenge in reconciling the ambiguity between (1) complicating the field's monolithic sense of its history, the so-called "master narrative," and (2) solidifying the field's political influence by reifying its core assumptions. At stake is the development, or not, of critical perspectives necessary to advance the progressive pedagogical, disciplinary, and political goals implicit in claims to "revisioning."

At the risk of belaboring the point, I want to reiterate this is not an attack on the quality of Gold's historical work. It is, rather, an attempt to indicate a gradual reorientation of disciplinary exigencies during the past three decades. In fact, I contend that this reorientation is a function of the revisionary historiographical frame. I want to offer a second example to illustrate what I mean and demonstrate some ways that now-conventional appeals to broadening limit the critical purposes to which contemporary revisionary historiography may be put.

My second example is Shane Borrowman's “The Islamization of Rhetoric: Ibn Rushd and the Reintroduction of Aristotle into Medieval Europe.” Again, I chose Borrowman's essay because of its excellence, indicated by its selection as Rhetoric Review's 2008 “Best Essay of the Year.” Borrowman argues that Aristotle's Rhetoric received important, and under-recognized, translation and preservation in the hands of Ibn Rushd, a well-known twelfth century Arab scholar. Among Borrowman's significant contributions is his powerful critique the "myth of 
cultural authenticity," which shaped the reception of Aristotle's work in the West for centuries. This myth encompasses the belief that Western culture developed in a hermetically sealed cultural container - the Occidental tradition untainted by the Orient (346). ${ }^{13}$ Borrowman argues that recognizing Arab scholars' contributions allows rhetoricians to reread Aristotle's corpus in meaningful ways. His history, therefore, revises one of rhetoric's canonical texts and recovers the contributions of an historical actor whose work has been overlooked/suppressed in the Western canon. As such it seems initially to exemplify the critical interrogation I am advocating. To the contrary, however, I suggest that Borrowman ultimately sidesteps critique.

I have no quibble with Borrowman's research, to be sure, but his groundbreaking research resides in an uncomfortable tension with his revisionary frame. After building a strong case for re-seeing Aristotle's Rhetoric in light of its Arabic influences, Borrowman concludes with a seemingly minor point: the period in which Ibn Rushd lived and worked demands more historical recovery. Borrowman writes, "My efforts at historical recovery begin with Ibn Rushd, but much work must be done as the rhetorical tradition's development in the overlap between the

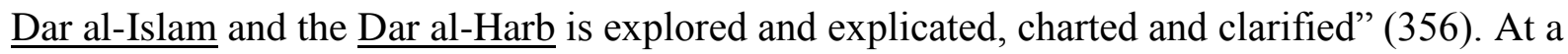
glance, this comment is simply intended to tie the essay up. But it is also an explicit declaration of the implications of his work, and it is peculiar given the import of his historical claims. In fact, it is more than passing strange that Borrowman's parting words do not encourage rhetoricians to rethink the entire Western rhetorical tradition, as we might expect from the rest of his essay. If revisionaries conventionally argue that the canon is flawed, Borrowman's research indicates an even more radical implication - the canon was never really the canon! Borrowman, however, redirects readers away from productive critique to the broadening imperative - to "explore and 
explicate, chart and clarify" medieval Arab scholarship. It is a direct inducement to a fuller, more comprehensive history.

In short, Borrowman's closing statement privileges revisionary historiography over the critical implications of his work. I do not contest the importance of histories that explore new rhetorical territories, nor am I suggesting Borrowman wanted to downplay the critical implications of his research. But, the incongruity between his critical discoveries and his concluding exhortation calls attention to the conventions of his revisionary frame. Throughout his essay, Borrowman suggests new ways to read Aristotle in light of Ibn Rushd's work, and he might have concluded by prodding readers to revisit Aristotle — not to reconstitute the canon, but to critically engage "myths" that go unnoticed in rhetorical studies'. In other words, Borrowman might have ended with a call to critique/critical reflection. Instead, he appeals to the broadening imperative - to historians' perpetual search for broader horizons in the service of more complete historical knowledge. Whatever his intention, Borrowman ultimately obviates critical interrogation in favor of historical accretion.

\section{Provisioning Rhetoric: A Critique}

Gold and Borrowman's histories are a few years old, but they nevertheless illustrate the broadening imperative as a methodological convention of contemporary revisionary histories — a convention largely detached from the first-generation revisionary search for critical perspectives. In separating the broadening imperative from critique, my goal is neither to revive canon-busting nor to undermine contemporary revisionary histories in toto. But I do want to recuperate the firstgeneration critical orientation that required openly interrogating rhetorical histories' underlying methodological assumptions. I am not necessarily calling for new historiographical modelsanother essential first-generation pursuit which has recently been revived (e.g., Ballif, Theorizing 
and "Untimely"). Rather, I am calling for reviving critique, which resides alongside and in tension with new histories and historiographies. This first-generation critical practice, as much as the revisionary histories themselves, strengthened the field by holding rhetorical scholars accountable to one another. Critique effectively replaced the canon as historians' common grounding, but it has been superseded by the broadening imperative. In what remains, then, I offer a brief example of what reviving critique might look like.

As I initially conceptualized this essay, my inclination was to define the "broadening imperative" in terms of colonization. I am not the first person to suggest that revisionary histories involve an element of empire building (Crowley, "Let's Get"; Swearingen; Vitanza "Taking”). Indeed, revisionary history has long evinced potential affinities with colonization. When, for example, Cheryl Glenn says that Aspasia’s significance "lies in the establishment of her own colony in ... the patriarchal territory of exclusionary rhetoric" and "The future of rhetoric, the rhetorical frontier, awaits our further explorations, settlements, and mappings," ("Locating” 35), readers are coached to think in the language of colonization, empire, and Manifest Destiny.

Ultimately, however, the charge of colonization is unconstructive. For one, it is unnecessarily hyperbolic - despite the perpetual appeal to broadening, the restricted goals of shaping pedagogy and discovering overlooked historical subjects hardly assume the awesome power of empire. It seems appropriate to reiterate that critique does not mean obliteration. Moreover, the charge of colonization carries the implicit assertion that revisionary history should be abandoned. I do not think this is the case given the contributions of revisionary histories outlined above. Nonetheless, the coupling of perpetual expansion with ideological preservation in the name of "progress" bears further scrutiny. 
In place of colonization, therefore, I offer the concept of "provisioning." 14 By

provisioning, I refer to the stocking of basic supplies in preparation for a natural disaster or when embarking on a potentially dangerous expedition (say, a flight to the moon). Provisioning is a useful metaphor for considering the expansionist tendencies of revisionary historians because the goal is not to conquer virgin territory and assimilate (or eradicate) the natives. It is to guarantee oneself enough essential provisions in case of emergency. Taken at face value, Gold's suggestion that policymakers and publics care about nuanced disciplinary histories is curious. For one, "policymakers" and "nuance" are not commonly associated with one another. However, Gold's claim is more understandable if we imagine that historians are tasked with demonstrating rhetoricians' long history as reliable pedagogues.

When crisis hits, as seems inevitable, and when tough decisions have to be made about the future of higher education, rhetoricians want to be well provisioned to demonstrate their lasting value. The implication is that a tradition of empowering students, linking rhetorical instruction to democratic action, and developing locally responsive pedagogies will validate the field and earn rhetoricians a voice in discussions about the future. In this context, broadening corresponds to gathering essential supplies rather than conquering territories. Obviously, Gold was not intentionally arguing for provisioning rhetorical studies, but the underlying assumptions on which he stakes his claims allow for such a critique.

Provisioning for a crisis can be crucial, of course, and given the historical "anxieties" in rhetorical studies (see Schilb, "Future"), the impulse to provisioning is understandable. But as Crowley points out, "rhetoricians are not particularly anxious about the survival of their discipline, either locally or globally" anymore ("Afterword" 195). This is not to suggest there are not crises to be provisioned against. Rather, the broadening imperative which ably addressed 
crises thirty years ago is unlikely to address crises in the 2010s. In other words, provisioning is not well suited to revealing and addressing contemporary concerns in rhetorical studies.

Taken to a logical extreme, provisioning may even become self-destructive hoarding. We might productively revisit our apocryphal rhetoricians on the moon here. Under the auspices of provisioning, Neil, Buzz, and the other astronauts might reasonably be considered "excluded" from the history of rhetoric. Moonwalkers who have not received the same attention as Armstrong and Aldrin, especially, may be imagined as forgotten, excluded, or silenced. In the logics of revisionary provisioning, astronauts are perfectly good candidates for developing "truer narratives" and "more nuanced" histories. In this regard, Armstrong and Aldrin are no less suitable than any other historical subject(s). Outlandish though this example may seem, it is not inconceivable. After all, Ibn Rushd was famous enough in his own time to merit inclusion in Dante's Divine Comedy (Borrowman 342).

At this point I might ask my title question in earnest: Who cares if rhetoricians landed on the moon? If the intrinsic motivation is provisioning the field against crisis, we might convince ourselves that "recovering" astronauts is important because they can convince administrators, politicians, or publics to value rhetoric. But, of course, while Armstrong and Aldrin may be "excluded" from the history of rhetoric, they are not "excluded" from world history. Rhetorical astronauts, therefore, illustrate crucial drawbacks of provisioning - the implicit search for credibility effectively closes down the systematic interrogation of the status quo which constituted the great strength of first-generation revisionaries. Consequently, provisioning threatens to reintroduce old hegemonies under the guise of "excluded" subjects. It is this sort of inadvertent progression that critique is meant to confront.

\section{Critical Conclusions}


Before concluding, it is incumbent upon me to articulate briefly what critical historiography can be. For one: critical. James J. Murphy notes in the first "Octalog" that histories entail varying perceptions about "what ought to be discovered for the good of the community" ("Octalog" 5). In revisionary provisioning, the "good of the community" is a grounding concept, but for critical revisionaries both "good" and "community" must remain available for reconsideration. As I mentioned above, first-generation revisionaries examined the past to denaturalize the present - it was not a simple quest for new voices, but a constant process of re-examining relationships of language to power. In this process, the central critical question is: What can we discover in the past to help us rethink our most established beliefs in the present and act differently in the future? As Pat J. Gehrke writes, "If we can follow the traces of some of these [marginalized, excluded, or silenced] discourses in our own discipline, then we might begin to chart alternative paths that have always been open in our history" (emphasis mine 355). In other words, a critical orientation is essentially introspective and charts new/old paths that we have obscured from ourselves. It is a meditation on "the good of the community," not just a prescription for maintaining the community we are.

The possibility for critical introspection is available in all the examples I introduced above, but perhaps the clearest articulation can be extrapolated from Ronald Jackson's critique of progressive pedagogy. Jackson pointedly asks what kinds of "political, cultural and social unfreedom[s]" we leave for our children by cleaving uncritically to a legacy of "mainstream rhetoric" (Octalog III" 117). His critique is striking for several reasons, but perhaps most of all because it seeks to denaturalize rhetorical studies by asking, and inviting readers to ask, what assumptions we embrace when teaching (and studying) the history of rhetoric; what potential harm we do as a result; what actions we can take for "the good of our community"; and what we 
think we mean by "good" and "community." His conclusions are not comforting. Jackson's critical stance is clearly not designed to reinforce the status quo (i.e., provision the field) and enable external political action, but neither is it an attempt to destroy rhetorical studies. Rather, it is an attempt to discover alternative, overlooked paths within rhetorical studies and chart new ways to act. Ultimately, this is the promise of critical historiography. Under the right circumstances, astral rhetoricians or rhetorical astronauts might illuminate such paths if they offer "new conceptions of the past" and "new interpretations of the present" (Berlin, "Histories" 122). But lunar or otherwise, re-visioning should entail critically examining, and even openly contesting, the field's cherished ideological commitments.

It is tempting to conclude here with another convention of revisionary historiography: a plea for historians to announce their "situatedness" (Berlin, "Histories” 121). Announcing one's situatedness is a laudable goal, of course, but as rhetoricians are aware, people do not always know what they do not know. Ultimately, historians cannot always recognize, much less announce, their loyalties. What historians can do is revive the politics of historiographyspecifically its attendant tradition of critique — by “question[ing] the limits of [one another's] most sure ways of knowing" (Butler 215). Michelle Ballif contends in Theorizing Histories of

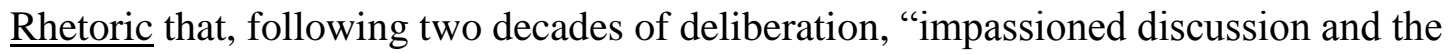
metatheorization [of rhetorical historiography] have fallen silent" (2). This silence resulted partly from calls for "tempering our recent preoccupation with historiographic theory" in favor of attending to historical methods (Ferreira-Buckley 577). These calls have been heeded to good ends, but in concert with reviving historiographic theory as advocated by Ballif and others, it is time to reintroduce historiographic critique to augment the valuable work in rhetorical histories and methods. 
Ultimately, historians should not stop writing revisionary histories, nor has "broadening" run its course as a valuable historiographical trope. There are undoubtedly historical horizons that bear exploration. Nevertheless, if we hope to realize the radical possibilities of broadened horizons, historians must paradoxically recuperate a feature of the old canon wars: openly and critically interrogating one another's methodological assumptions, not in order to reject them, but to hold them open for productive discussion. Whereas Crowley sees the decrease in "fervor" over historiographical theorizing as a happy sign of a maturing field, I am rather inclined to agree with Victor J. Vitanza that fervent wrangling is "a sign of great ferment" ("After/word" 234). Fervor has a way of holding us accountable to others for "situatedness" that we cannot recognize in ourselves. And so I conclude here with a call to (re)turn to fervor and a (re)turn to productive historiographical critique. Ultimately, if we hope to boldly go where no rhetorician has gone before, we would be well served, to paraphrase Pat Gehrke, by making what is familiar in rhetorical studies appear alien once again. 


\section{Notes}

${ }^{1}$ Many thanks to Jess Enoch, Kendall Gerdes, Matthew Heard, Judy Holiday, Davis Houck, Kyle Jensen, Jen Wingard, Kelly Wisecup, Victor J. Vitanza, and Jim Zebroski for their patient guidance in this essay's long development. Thanks especially to Jen Wingard and Jim Zebroski for inviting me to present an earlier version of this essay as part of the University of Houston's “Martha Gano Houstoun Distinguished Visiting Professor in Literary Criticism” speaker series. And finally, thanks to $\underline{\mathrm{RR}}$ reviewers Michelle Ballif and John Schilb for their generous readings and constructive comments.

${ }^{2}$ The others are: Pete Conrad, Alan Bean, Alan Shepard, Edgar Mitchell, David Scott, James Irwin, John W. Young, Charles Duke, Eugene Cernan, and Harrison Schmidt.

${ }^{3}$ See Swearingen and Schiappa for a good overview.

${ }^{4}$ Many historians reject Berlin's neo-Marxist politics, but revisionary histories are often linked to progressive politics (e.g., Ferreira-Buckley; Schilb, “Differences”).

${ }^{5}$ See Zebroski for a compelling case for critique in rhetorical studies.

${ }^{6}$ For examples of recent historiographical work that resists the revisionary frame, see Ballif, "Historiography"; Hawk; and Vitanza "Philology".

${ }^{7}$ A cursory glance reveals that revisionary histories have won several major awards in recent years, including book awards from $\underline{\mathrm{CCCC}}$ and $\underline{\mathrm{JAC}}$ and essay awards in $\underline{\mathrm{Rhetoric} \text { Review}}$, College English, and Rhetoric Society Quarterly.

${ }^{8}$ I recognize the distinction between "first-generation" and "contemporary" is ill-defined and somewhat arbitrary. This is not unintentional. Some historians are demonstrably both. As Vitanza points out, “[S]eldom does any one historian function exclusively in any one category of 
historiography, though s/he may, indeed, for the most part emphasize one over the others" ("Notes" 85).

${ }^{9}$ I am grateful to John Schilb for reminding me that revisionaries had diverging orientations to conventional politics (see, e.g., Enoch; “Octalog”).

${ }^{10}$ Crowley specifies the canon in "Let Me Get This Straight" (18n4).

${ }^{11}$ In a recent issue of Rhetoric Review, panelists from the first two Octalogs reflected on the state of rhetorical historiography following the third "Octalog" (see Agnew). Virtually every contributor notes the ongoing project of "pushing back the uncharted and unexplored areas of our field while (at the same time) being inclusive" (Agnew 244-245).

${ }^{12}$ Vitanza's refrain that recovering "the excluded third" is not liberatory is worth revisiting on this point (e.g., "Taking"), as are Vitanza's other considerable contributions to revisionary historiography, both as contributor and antagonist. See Worsham for a compellingand still incisive - argument that challenges the field's ideological commitments.

${ }^{13}$ See Bernal for a similar, if farther-reaching, critique.

14 Thanks to Kelly Wisecup for suggesting the concept of provisioning. 


\section{Works Cited}

Agnew, Lois, et. al. "Rhetorical Historiography and the Octalogs.” Rhetoric Review 30.3 (2011): 237-57.

Ballif, Michelle. "Historiography as Hauntology: Paranormal Investigations into the History of Rhetoric.” Ballif Theorizing 139-53.

---. "Introduction.” Ballif Theorizing 1-7.

---, ed. Theorizing Histories of Rhetoric. Carbondale: Southern Illinois UP, 2013.

---, ed. “Untimely Historiographies.” Spec. issue of Rhetoric Society Quarterly 44.3 (2014).

Berlin, James A. "Revisionary Histories of Rhetoric: Politics, Power, and Plurality.” Vitanza Writing 112-27.

---. "Revisionary History: The Dialectical Method.” Rethinking the History of Rhetoric: Multidisciplinary Essays on the Rhetorical Tradition. Ed. Takis Poulakos. Boulder: Westview, 1993. 135-52.

Bernal, Martin. Black Athena: The Afroasiatic Roots of Classical Civilization. Vol. 1: The Fabrication of Ancient Greece, 1785-1985. New Brunswick: Rutgers UP, 1987.

Blair, Carole, and Mary Kahl. "Introduction: Revising the History of Rhetorical Theory." Western Journal of Speech Communication 54.2 (1990): 148-59.

Borrowman, Shane. "The Islamization of Rhetoric: Ibn Rushd and the Reintroduction of Aristotle into Medieval Europe.” Rhetoric Review 27.4 (2008): 341-60.

Butler, Judith. "What Is Critique? An Essay on Foucault's Virtue.” The Political. Ed. David Ingram. Oxford: Blackwell, 2002. 212-26.

Carter, Shannon, and James H. Conrad. "In Possession of Community: Toward a More Sustainable Local.” College Composition and Communication 64.1 (2012): 82-106. 
Crowley, Sharon. “Afterword: A Reminiscence.” Ballif Theorizing 190-5.

---. "Let Me Get This Straight.” Vitanza Writing 1-19.

Enoch, Jessica. "Releasing Hold: Feminist Historiography without the Tradition.” Ballif Theorizing 58-73. Print

Ferreira-Buckley, Linda. "Rescuing the Archives from Foucault." College English 61.5 (1999): 577-83.

Foucault, Michel. "Practicing Criticism.” Politics, Philosophy, Culture. Ed. Lawrence D. Kriztman. London: Routledge (1988): 152-6.

---. "What is Critique?" The Politics of Truth. Ed. Sylvère Lotringer and Lysa Hochroth. New York: Semiotext(e) (1997): 23-82.

Gaillet, Lynée Lewis. “(Per)Forming Archival Research Methodologies.” College Composition and Communication 64.1 (2012): 35-58.

Gehrke, Pat J. "Historical Study as Ethical and Political Action.” Quarterly Journal of Speech 93.3 (2007): 355-7.

Glenn, Cheryl. "Locating Aspasia on the Rhetorical Map.” Listening to Their Voices: Rhetorical Activities of Historical Women. Ed. Molly Meijer Wertheimer. Columbia: U of South Carolina P, 2007. 19-41.

---. Rhetoric Retold: Regendering the Tradition from Antiquity Through the Renaissance. Carbondale: Southern Illinois UP, 1997.

Gold, David. "Remapping Revisionist Historiography." College Composition and Communication 64.1 (2012): 15-34.

---. Rhetoric at the Margins: Revising the History of Writing Instruction in American Colleges, 1873-1947. Carbondale: Southern Illinois UP, 2008. 
Graff, Richard, and Michael Leff. "Revisionist Historiography and Rhetorical Tradition(s)." The Viability of the Rhetorical Tradition. Eds. Richard Graff, Arthur Walzer, and Janet Atwill. Albany: SUNY, 2005. 11-30.

Hawk, Byron. "Stitching Together Events: Of Joints, Folds, and Assemblages." Ballif Theorizing 106-27.

Hesford, Wendy S. "Global Turns and Cautions in Rhetoric and Composition Studies.” PMLA 121.3 (2006): 787-801.

Jarratt, Susan C. Rereading the Sophists. Carbondale: Southern Illinois UP, 1991.

---. "Toward a Sophistic Historiography.” Pre/Text 8.1-2 (1987): 9-28.

McKee, Heidi, and James Porter. "The Ethics of Archival Research.” College Composition and Communication 64.1 (2012): 59-81.

Morris III, Charles E., and K.J. Rawson. “Queer Archives/Archival Queers.” Ballif Theorizing 74-89.

“Octalog: The Politics of Historiography.” Rhetoric Review 7.1 (1988): 5-49.

“Octalog II: The (Continuing) Politics of Historiography.” Rhetoric Review 16.1 (1997): 22-44.

“Octalog III: The Politics of Historiography in 2010.” Rhetoric Review 30.2 (2011): 109-34.

Poulakos, Takis. "Historiographies of the Tradition of Rhetoric: A Brief History of Classical Funeral Orations.” Western Journal of Speech Communication 54.2 (1990): 172-88.

Schilb, John. "Differences, Displacements, and Disruptions: Toward Revisionary Histories of Rhetorics.” Pre/Text 8.1-2 (1987): 29-46.

---. "Future Historiographies of Rhetoric and the Present Age of Anxiety." Vitanza Writing 12838.

---. “The History of Rhetoric and the Rhetoric of History.” Pre/Text 7.1-2 (1986): 11-35. 
Swearingen, Jan. "Back to the Future and Across the Oceans." Agnew 242-4.

Swearingen, C. Jan, and Edward Schiappa. "Introduction: Historical and Comparative Rhetorical Studies: Revisionist Methods and New Directions." SAGE Handbook of Rhetorical Studies. Ed. Andrea A. Lunsford. Thousand Oaks: SAGE (2009): 1-12.

Vitanza, Victor J. "An After/word: Preparing to Meet the Faces That 'We' Will Have Met." Vitanza Writing 217-57.

---. "Critical Sub/Versions of the History of Philosophical Rhetoric.” Rhetoric Review 6.1 (1987): 41-66.

---. Negation Subjectivity, and The History of Rhetoric. Albany: SUNY Press, 1997.

---. "'Notes' Towards Historiographies of Rhetorics; or, Rhetorics of the Histories of Rhetorics: Traditional, Revisionary, and Sub/Versive.” Pre/Text 8.1-2 (1987): 63-126.

---. “A Philology for a Future Anterior: An Essay-as-Seminar.” Ballif Theorizing 172-89.

---. “Taking A-Count of a (Future-Anterior) History of Rhetoric as 'Libidinized Marxism' (A PM Pastiche).” Vitanza Writing 180-216.

---, ed. Writing Histories of Rhetoric. Carbondale: Southern Illinois UP, 1994.

Worsham, Lynn. “Eating History, Purging Memory, Killing Rhetoric.” Vitanza Writing 139-55. Zebroski, James Thomas. "Critical Theory, Critical Pedagogy, and the Reconceptualization of Rhetoric and Composition." JAC 31.1-2 (2009): 283-307. 